\title{
Investors' Perception for Transforming Traditional Stock Market into Islamic Stock Market: An Empirical Study on Dhaka Stock Exchange
}

\section{Md. Saheb Ali Mondal ${ }^{1}$, Nazma Akter ${ }^{2}$, Mohammad Afsar kamal ${ }^{3}$}

${ }^{1}$ Assistant Professor of Accounting, DBA, International Islamic University Chittagong, BANGLADESH

${ }^{2}$ Assistant Professor of Accounting, DBA, Northern University Bangladesh, BANGLADESH

${ }^{3}$ Senior Lecturer, DBA, Uttara University, BANGLADESH

\begin{abstract}
Muslim investors should concern not only about maximizing profits but also be aware about the justification of Islamic guidelines and invest to whose stocks which are shariah compliant. The severity of the current market fall as well as financial crisis has shaken the foundations of the capitalist financial and capital market system and has led to search for ideas and solutions. So it is imperative to explore all possible approaches that enhance the process of mobilizing Islamic financial resources and expanding shariah compatible investment like investment in Islamic stock market. This paper is few attempts that identify some failures of conventional stock market as well as favorable position of Islamic stock market and investors' perception regarding the topic. Study covers 201 respondents to collect data and analyze it by using five point Likert scale. This study found that investors feel to get separate Islamic stock market with Islamic shariah and principles but not to transfer traditional stock market into Islamic stock market. The study revealed that they desire to get stable and minimum risk market for Islamic stock with halal income whereas they want to make more profit anyhow from the existing market preferably.
\end{abstract}

Key words: Islamic stock market, Stock market, Shariah principles, Investors' perception, Shariah compliant and non compliant stock

\section{INTRODUCTION}

Islam is a subject of unconditional option instead of mandatory and most of the people of our country are Muslims but their vital economy not depends on Islam. Moreover they do not consider absolutely practice in Islam, social welfare, shariah rules and regulations, equity based security, interest or riba, separate Islamic market, risk and return. In the case of Bangladeshi investors who seek to invest in shariah compliant stocks, interest rate is therefore not a determining factor. According to Prophetic saying "Islam has strictly admonished any deliberate pushing up of prices whether through monopoly or najash (pushing the prices up without actually intending to buy)". While the studies on conventional stock market are proliferating in the recent decades, less attention is being 
given to its Islamic counterpart. In convention market, there are several determinants of the share price movement that can drastically change the stock market scenario and most of them are prohibited in lslam but in order to make the stable Islamic market, there may have only one factor that should be principle of Islam. Investors should examine and take into account, where they invest and which one is appropriate for the earth and hereafter. The establishment of Islamic stock markets will be benefited for the investors, issuers and intermediaries as well as the country as a whole.

Mobilization of resources is needed to finance development projects in Muslim countries; the structure and scope of the Islamic stock market as well as its problem of raising funds require an in-depth examination in the light of the shariah. Islamic economists contend that Islamic finance has an alternative that would prevent the recurrence of a similar crisis, whereas the principles of Islamic finance have much to offer to bring out a stable financial system and capital market. Based on the literature review, there has been no study conducted on the implication of Islamic stock market in Bangladesh. This study attempts to fill this gap and suggest that investors should see how they will earn money from the market in the light of maqasid al shariah. The objective of this study is to critically examine the fact that whether the investor of DSE follow the determinants affecting stock price under Islamic frame work and to formulate the investors perception for considering Islamic concept instead of existing traditional market. Researchers tried to get the perception of investors, are they feel to convert existing stock market in Dhaka Stock Exchange into Islamic Stock Market or not? The study found that most of the respondents follow the shariah prohibited factors to invest and they are not fully agreed to transfer this market to Islamic stock market but feel to lunch separate Islamic stock market. But their behavioral approaches are not behind the Islam, hopefully, they want to get maximum benefit from Islamic market without having Islamic stock market. This study tries to furnish some concrete suggestions and recommendations towards the development of a full-fledged Islamic stock market.

\section{LITERATURE REVIEW}

Literature review presents previous research findings regarding existing market problems and prospects of Islamic stock market. In case of loan ratio, SEC changed directive of margin loan ratio by increasing it from 1:0.5 to 1:1 on 13th December 2010 and later it was again hiked to 1:1.5 \& 1:2 because of free fall of share prices (Bhuiyan, 2011). Hossain (2011) criticized "this time liable factors are omnibus account, placement share, book building method, rumors and so on. Misuse of those factors causes the capital market debacle". According to M. Shamsul Haque professor of finance and Vice Chancellor, Northern University Bangladesh (2012) "Combination of wrong information to the investors, illegal participation of banks and institutions in the stock markets, weak accounting functions are at the core of the crisis that saw billions of Tk. wiped out". Bangladesh government commissioned a committee consisting of four members led by Mr. Khondkar Ibrahim Khaled (chairman) to find out individual or institution involved in the recent share market crash. The committee submitted a report consisting of the reasons for the crash and recommendations with couple of case studies on 7th April, 2011. The report has identified a group of manipulators including key officials, auditors, issuers, issue-managers, brokers, individual investors and some other stakeholders. According to the investigation report (2011) of the probe committee, reasons for the stock market crash are following: role of market regulators and their employees; demutualization of exchanges; investment of bank in the capital market; pre-IPO \& IPO process; uniform face 
value of share; placement trade / kerb market; omnibus account; asset revaluation \& rumor; book building method; direct listing; block placement; suspicious transaction of top players; issue of right and preference share; serial and artificial trading. So we can say that Dhaka stock exchange is not in right track. Sangit Saha (2012) found that over exposure of banks \& financial institutions is the most important reason behind the crash where 15 respondents selected the cause. Then poor monitoring of regulators was found 2nd important reason for the crash chosen by 12 respondents. Corrupted employees of regulators, Margin loan were chosen by 11 respondents and direct listing \& insider trading was selected by 8 respondents.

Interest rate volatility affects the conventional stock market volatility but not the Islamic stock market volatility. And they stated that there is no evidence of significant time varying risk premium for both convention and Islamic stock returns (Mohd. Yusof and Abd. Majid, 2006). Risk free interest rate element can be influenced by the changes in money supply and thus affecting the expected return of a financial asset. An increase in the interest rate reduces stock prices and eventually the returns. They suggest that investing in Islamic stocks provides higher returns although it has almost similar risk to the conventional stock market. (Mohd. Yusof and Abd. Majid, 2007). Investors who seek to maximize profits trend to be more sensitive towards changes in interest rates. For Turkish stock market, higher interest rate affects the stock market volatility for the period 1988-1995 Muradoglu et al. (1999). Shiller (2003) urged, for higher returns can sometimes lead to moral hazard behavior that can 'encourage people to engage in destructive rather than productive acts' . Chapra (2008) attributes the crisis to inadequate market discipline resulting from lack of using profit-loss sharing modes of financing, expansion of the size of the derivatives, and the policy of 'too big to fail'. He calls for a 'new architecture' to prevent occurrence of similar crises. Siddiqi (2008) identified the root cause of the crisis as 'a moral failure that leads to exploitation and corruption'. He identified credit (liquidity) crunch, over-extended leverage, complexity of the products, and speculation and gambling (risk shifting) as the main features of the crisis. Coval and Stafford (2007) said that although stocks are fungible, fire sales have been shown to happen also in stock markets because other investors may not have sufficient buying capital when selling pressure is highest and capital is a low moving or because the stocks sold may have different characteristics from their preferred set. Habib(2009) revealed the key factors causing the crisis can be identified at three levels: a deregulated environment, financial institutions engaged in excessive risk-taking (to reap higher profits), and the use of innovative complex products. Sarah Gooden (2011) Generally speaking the key principle in Islamic finance is the need to achieve justice. The aim therefore is to avoid injustice to a party in a transaction. These include prohibitions against jahala (ignorance) and garar (speculation). Whilst it is acknowledged that it is impossible to remove all speculation or uncertainty from commerce, the intention is that avoidable elements of speculation should be removed and parties should be clear on the upon which they have agreed to do business. These principles mean that gambling \& many types of derivatives contracts, many forms of insurance, unfair advantage \& income from objects that are forbidden for a Muslim are not permitted under Shariah law.

Abdul Rahman Yousri Ahmed (1995) state that there are three conditions for a security to be Islamic: i. to be committed to the conditions of profit and loss sharing in a clear, unequivocal stipulation on the legal rules governing the mudarabah and partnership contracts necessarily but not sufficient. ii. Resources mobilized through these securities (issued on non interest basis) should not be rechanneled to institutions not functioning in conformity with Shari'ah and to firms dealing with interest in all their activities by using Islamic bank. 
Without sharing in the risk of this return, such returns are nothing but interest and the term profit is merely a misnomer just for covering it up. iii. The funds mobilized through these securities should be utilized in priority projects that clearly fulfill the public interest of the Muslim society and should not invest non Muslim foreign countries. Robbins (2010) stated that in the post-financial crisis would economy, there will be opportunities for new financial products to develop in response to both crisis and its regulatory fallout. The principles of Islamic finance may be just what are needed in this trying economic time, with an emphasis on morality, fairness and aversion to excessive risk, these foundational premises can teach conventional finance a few helpful lessons. The key will be to find ways to translate Islamic finance's underlying goals and methods to a large audience in the non Muslim world. Samad \& Hassan (1999) found that BIMB (Bank Islam Malaysia Berhad) is relatively more liquid and less risky compared to a group of 8 conventional banks.

A true Muslim will not consider it a great sacrifice when he parts with his surplus liquidity because Islam urges him to invest his idle balances in productive activities which may benefit the Islamic society, yet he will not hesitate to seek the optimal investment opportunities likely to provide him with a better yield. Therefore, the best securities to a Muslim are those issued (a) by ventures serving the objectives of Islamic economic activity, (b) projects expected to yield higher returns, (c) the Muslim buyer who acquires them will not feel embarrassed to take advantage of price changes through the sale of securities in his possession or repurchasing them later on for the benefit of achieving windfall profits from this transaction as long as (i) he is not linked whether as a major or secondary contributor, to the price changes which he would have taken advantage of, and (ii) he has concluded the transaction in accordance with the terms set out by the security issuing party. Brooks (2009) asserts that 'an economy is a society of trust and faith' and 'every recession is a mental event' and 'has its own unique spirit'. Secondary securities markets in most Muslim counties are almost non-existent, or where they exist, are unorganized, or are regulated by laws and regulations that do not allow sufficient dynamics required to achieve their objectives, especially if we take into consideration the nature of the institutions that dominate them.

Islamic capital market means where investment and financing activities and products are structured in accordance with shari'ah principles. Bursa Malaysia's definition is (taken from the Islamic Capital Market, p. 2): "The Islamic Capital Market (ICM) refers to the market where activities are carried out in ways which doesn't conflict with the principles of Islam. Therefore, it is of utmost importance to analyze the Shari'ah appraisals on the existing stock market in to see if it is permitted in Islam, or totally prohibited, or allowed with certain modifications of existing share and bond of DSE. The classical literatures on Islamic jurisprudence include the basic Shariah principles for financial transactions like prohibition of Riba, gambling, AlGharar, coercion, cheating and the Shari ah rulings for partnership business and various types of contracts and the legal maxims for issuing Fatwa in the new issues. (See Ibn Taymiyah, 1999). Fahd have explained in detail the permissibility of a share market in Islamic Shari ah but the other parts related to the share market are absent in their studies. Fahd (2007) argued that the share of a company is perfectly legal and that there is no prohibition whatsoever for establishing share market in Islam. (Zaky, (1992) asserts that the ordinary share is lawful, but the preferred share is not, as he says: "while investment in ordinary shares is perfectly lawful, investment in preferred share is not". (p. 71) 


\section{MetHodology}

The nature of the study is descriptive and empirical. Primary data have been collected throughout the structured questionnaire from the 201 respondents randomly from the different brokerage houses which have been selected on the basis of purposive sampling in the Dhaka city. Most of the investors were not interested to response even they had fear and insulting mode. After collecting the data researchers used Five point Likert scale and Cronbach's Alpha test for analysis. Likert five points scale used an equal weight of each length in the study, used degrees as follows: not influenced, slightly influenced, moderately influenced, influenced and strongly influenced. The highest grade given 5 degrees, the lowest grade given one degree, the degrees sorted in descending order $(1,2,3$, $4,5)$. Secondary information has been taken from the data base of DSE. Total 301 companies listed up to march-2013 in DSE which has outstanding common share to the investors and study identified how many companies are Islamic on the basis of shariah board or product and services. Treasury stock, preferred stock and bond \& debenture are not considered to analyze because of their shariah non compliant character.

\section{ReCOGNIZED PROBLems OF DHAKA Stock Exchange}

Dhaka Stock Exchange establishes and executes rules and regulations to conduct all the activities smoothly \& efficiently and control them properly and timely on the basis of conventional approach. But Dhaka stock exchange failed to run \& control smoothly and efficiently due to some problems and most of them undoubtedly, prohibited in Islam. Researchers found some problems which were causes the big crash of DSE and can be summarized as: gambling; insufficient and inefficient monitoring; euphoria of investment in shares; prospect of quick capital gains; existence of kerb market; absence of proper application of circuit breaker; lack of skilled manpower and their inhuman behavior; price manipulation; delays in settlement; irregulations in dividends; selection of membership; improper financial statement; the intrinsic values of the securities; the absence of comprehensive legal and supervisory framework; the lack of proper policy framework that provides incentives and protections; government forms the institutional sources rather than the market; not well developed and weak form market; political involvement; illogical involvement of bank \& other funds which are responsible for pushing the market to speculative activities. Delivery versus payment mechanism was used as one of the main vehicles of manipulation. Other reasons: profits \& sales slipping; authority does not hold required shares; top executives leave the company; a famous investor sells shares of the company; an analyst downgrades his recommendation of the stock, may be from "buy" to "hold"; other stocks in the same industry go down; shortage of share supply, a big lawsuit is filed against the company; some new law might hurt sales or profits and a powerful company enters the business. These problems are identified on the basis of literature but most of them are inconsistence with Islamic law and shariah, this is why the study tried to focus investors' perception to transfer this market into the Islamic stock market for betting the existing problems as much as possible.

\section{Why AND HOW ISLAMIC STOCK MARKET IN DHAKA STOCK EXCHANGE?}

Investors' Islamic values and morality depend upon the Islamic economy as well as total Islamic environment. Therefore creation of an Islamic values and morality of the investors and common Islamic stock market is the desire of the muslim investors. And of course, it will be efficient and sound for trading Islamic stocks and to invest in profitable and shariah compliant securities and instruments. In order to get minimum or equal risk and 
stable market, what are the dealings and transactions that are required to give life to the market to identifying the "permissible" transactions in the light of maqasid al shariah? It is Islamic stock market but stock market based strictly on Islamic principles is still in the early stages of its evolution especially in Bangladesh. To do this, we need a sound Islamic money market and various Islamic companies and after that investors can get the Islamic stock as well as market. The first step in establishing an Islamic stock market would be to rid the conventional system and riba, or interest. A systematic understanding of stocks from Islamic perspective is necessary, but, without having an Islamic shariah or shariah advisory council we can't touch the uplifting position, even to start. So we must look at the shariah board or shariah advisor council before trying to establish any legal actions. Moreover, this development based on Islamic principles are based on the interpretations of shariah is part of an ongoing process. Others aim to help the harmonization of Islamic accounting standards; to build a halal income source from stock; increasing degree of integration and to create attraction to invest among Muslim countries.

According to shariah, gambling is forbidden as stated in the Holy Quran. It is true that people are not willing to take a greater degree of risk except against a greater amount of expected return but gambling profit is not a reward for that. Islam has strictly admonished any intentional pushing up of share prices through gambling. As for safeguarding the market and the Islamic economic activity against illegal price speculation, Islamic stock market may be the solution of removing all the causes which lead to it. Therefore, it is one of the functions of an Islamic secondary market to eliminate speculation and to impose tight controls non-shariah price speculations.

Islamic stock market requires an equity based securities not debt-based securities. But equity based security does not indicate purely Islamic or shariah-compliant stocks. Shariah-compliant in Islamic perspective, if their business activities are not related to prohibited activities as outlined by shariah scholars. The prohibited business activities include: alcohol, gambling, pork-related products, pornography, conventional financial services, conventional insurance, weapons, hotels or entertainment depending on the methodology. Shariah, a framework of ethical guidelines or a set of principles that says you cannot be investing in industries which are harmful to one's self or to the society. Investors of Dhaka stock exchange are investing in companies that engage in financial services based on riba (interest), manufacture or sale of non-halal products or tobaccobased products or related products, gaming and gambling, conventional insurance, and non-compliant entertainment services, stock broking or share trading in shariah noncompliant securities and other activities deemed non-permissible according to shariah.

The establishments of an Islamic secondary stock market will not come out as a natural development in the existing economy. Actually it would be the output through Islamic studies regarding its laws, regulations, objectives, functions and by the desire of the investors and respective authorities. Islamic laws, regulations and objectives can formulate easily than its functions. Operational functions are more wide and complex to run and control. In the functions, Islamically oriented projects are expected to increase and it to be obtained by entering to the financial market directly through launching their own securities to cover their long-term financing requirements. Some Islamic banks, insurances and financial institutes have already taken this step of getting into the financial market and have issued securities that would enable them to response to the needs of projects seeking growth. But these attempts are like a drop of water in the river in Bangladesh economy. However, this trend is expected to increase in future within the need for a shariah-based security. There should have the capability to translate the relevant part of the Islamic shariah into the 
form of essential regulations and systems to the investors that would contribute to set up a secondary stock market which will be capable of meeting the challenges of our modern life. They should also have enough human expertise with some shariah scholars to run the activities of this market successfully and to ensure that it would not deviate from fulfilling the shariah objectives and the greater interests of the Muslim ummah.

Islamic capital market fact finding report (2004): Islamic scholars consider two additional criteria to select a company whether it is permitted or not with activities comprising both permissible and non-permissible elements: (a) The public perception to the company must be good; and (b) The core activities of that are important and considered maslahah (benefit in general) to the Muslim ummah (nation) and the country as well, and the non-permissible element is very small, difficult to avoid and the rights of the non-Muslim community which are accepted by Islam. In addition to the business activities criteria, certain jurisdictions use financial ratios as additional criteria in classifying shariah stocks. Other than business and financial criteria, some jurisdictions are known to also apply a cleansing mechanism to purify investments that are tainted by prohibited activities and that should goes to the charitable fund or baitulmal as shariah non compliant income. In our country, there is no Islamic economy by law and practice. So financial institute and listed company of DSE cannot avoid interest and few other things which are imposed by the government to the system of economy. Although the product or company is shariah compliant but financial and money market instruments, systems, laws and practices are not totally permissible to Islamic shariah. Neutral stock or partial Islamic stock means that those share are not absolutely haral or haram. Islam permitted those shares by trading and prohibited to take any kind of dividend. In those companies main business or end-product are halal but they borrow money on interest, also they invest some of their money on interest. Means, their business is mixed with interest. So there should have some tolerable limit of mixed contributions from permissible and non-permissible activities towards turnover and profit before tax of a company. In these regard, qualified shariah scholars fixed the benchmark and if the contributions from non-permissible activities exceed the benchmark, the securities of the company will be classified as shariah non-compliant. The benchmarks are: a. the five-percent benchmark: This benchmark is used to assess the level of mixed contributions from the activities that are clearly prohibited such as riba, gambling, liquor and pork. b. The 10-percent benchmark: This benchmark is used to assess the level of mixed contributions from the activities that involve the element of "umum balwa" which is a prohibited element affecting most people and difficult to avoid. An example of such a contribution is the interest income from fixed deposits in conventional banks. This benchmark is also used for tobacco-related activities. c. The 20-percent benchmark: This benchmark is used to assess the level of contribution from mixed rental payment from shariah non-compliant activities such as the rental payment from the premise that involved in gambling, sale of liquor etc. d. The 25-percent benchmark: This benchmark is used to assess the level of mixed contributions from the activities that are generally permissible according to shariah and have an element of maslahah to the public, but there are other elements that may affect the shariah status of these activities. Among the activities that belong to this benchmark are hotel and resort operations, share trading, stock broking and others, as these activities may also involve other activities that are deemed non-permissible according to the shariah. Purely Islamic common stock or shariah compliant stock \& warrants may be considered as shariah non compliant stock if company change totally or partially its operations and objectives or due to other causes.

On the other hand, if existing market is transferred to Islamic stock market and, or company changes its functions and objectives then shariah non compliant stock may be 
the shariah compliant stock. There will have some criteria that investors should follow. In this case what principles investors should follow is stated by distinguish shariah scholars and shariah advisory council which are as follows: (i) Shariah-compliant securities but changes in the companies' operations or due to certain reasons are subsequently considered shariah non-compliant. In this regard, the value of the securities held exceeds the original investment cost from effective date; investors who hold such shariah noncompliant securities must liquidate them and any capital gains arising from the disposal of the shariah non-compliant securities can be kept by the investors. But any excess capital gains derived from the disposal after effective date should be channeled to the charitable fund or baitulmal. (ii) investors who invest based on shariah principles to dispose of any shariah non-compliant securities which they presently hold, within a month of knowing the status of the securities. Any gain made in the form of capital gain or dividend received during or after the disposal of the securities has to be channeled to charitable bodies or baitulmal. The investor has a right to retain only the original investment cost.

With some specific regulations, existing securities will also be applicable to the Islamic markets and new stocks will have Islamic rules completely at the time of lunching. National shariah council is necessary to formulate for the Islamic financial money markets and capital markets. The Securities Commission and shariah council will work closely with the industry to encourage the introduction and promotion of new products according to Islamic shariah and advice them how to overcome the obstacle. Government, SEC and other respective authority should organize talk show, exhibition, seminar \& symposium and other promotional activities that will produce educational materials to the different target groups and it will help the existing and prospective investors to invest \& generate halal income from the market. The buildup of Islamic stock market and extended it to both regionally and internationally may be the opportunity of getting leading position in the world.

\section{ANALYSIS AND FINDINGS}

Islam is a way of life that can bring an alternative and create a healthy environment to the stock exchange. The resources are for the benefit of all, not just a few. So everyone must acquire resources rightfully and in accordance to the Quran and the Sunnah. But investors in DSE commonly do not follow those principles right now. The researchers made an effort to furnish investors' perception regarding the study object whether they are interested to invest into the Islamic stock market with accepting shariah law or not.

\section{Empirical ANALYsis}

Ranking of investors perception vary from one another. In this case, the investors perception regarding shariah rules \& regulations and separate Islamic stock market take place 1st position which are about 3.49 score. It indicates, Investors perception is negative to transfer conventional stock market into Islamic stock market and they are influenced to use separate Islamic stock market with shariah rules and regulations for that. They desire to get Islamic product and instrument and equity based security at the same time they like to enjoy interest but it opposite direction to others, both obtained 3rd position with 3.19 scores. It means that they have no appropriate concept of Islam or they want to get maximum benefit from both principles. From the table, study revealed that shariah advisor obtained 6th position which means investors moderately influenced with the necessity of shariah advisor for separate Islamic stock market. Islamic stock market would be less risky and provide secured return and shariah principles is compulsory for that which 
obtained 2.93 scores with bearing the meaning of moderately influenced. However, they have given priority to Islamic stock market, gambler involvement in the market, preferred stock, brokerage service and debt securities with scores 2.81, 2.76, 2.57 and 2.48 respectively which include strength and weakness of the stock market. Lastly, transforming existing market obtained last rank with a score 2.28 which means they are not influenced to transfer existing stock market to Islamic stock market. On the basis of five point Likert scale study claims that Investor has given priority about separate Islamic stock market with Islamic law; shariah council where there will be no interest and gambler and they are not influenced to transfer existing conventional market to Islamic stock market.

Cronbach Alpha reliability test

\begin{tabular}{|c|c|}
\hline \multicolumn{2}{|l|}{ Reliability Statistics } \\
\hline Cronbach's Alpha & N of Items \\
\hline .655 & 40 \\
\hline
\end{tabular}

Determining the reliability of data analysis is essential to ensure the trustworthiness of the study. Cronbach's alpha is a coefficient of internal consistency to estimate of the reliability of the statistical outcome from data and indicates inter correlations among test items with reliability of test scores. This study is based on primary data and most of the questions were commonly unfamiliar to the investors. So measurement of reliability is essential and Alpha Cronbach provides accurate internal consistency estimation and reliability. Table shows that the reliability coefficient is 0.655 . In other words, the overall questions are about $65.5 \%$ reliable and $34.5 \%$ unreliable which means reliability statistics is acceptable. There is no strong internal consistency among the test items. The study had argued that there are two views to poor consistency among the items. Investors want to get the benefit of Islamic stock market but they are used to make illogical and unethical profit from existing traditional market with a shorter period and want to continue it drastically.

Summary of Islamic \& non Islamic shares in DSE

\begin{tabular}{|c|c|c|c|c|}
\hline Basis & $\begin{array}{c}\text { Total shares } \\
\text { in DSE }\end{array}$ & $\begin{array}{c}\text { Islamic } \\
\text { shares }\end{array}$ & $\begin{array}{c}\text { Non Islamic } \\
\text { shares }\end{array}$ & $\begin{array}{c}\% \text { of Islamic } \\
\text { shares }\end{array}$ \\
\hline Shariah Board & 301 & 15 & 286 & 4.98 \\
\hline Products \& Services & 301 & 165 & 136 & 54.82 \\
\hline
\end{tabular}

Source: DSE database.

From the above table, we see that total listed companies are 301 in Dhaka stock exchange which have the common stock. On the basis of shariah board 15 companies are Islamic which indicates $4.98 \%$ of total stocks. So it has no significant number of Islamic stocks to start Islamic stock market. The study claims that, every organization should take necessary step to establish shariah board or shariah advisory council to make it Islamic company. But in view point of product and services 165 companies are Islamic which indicates $54.82 \%$ of the total shares. This number would be significant if we want to start Islamic stock market. However, only shariah board or Islamic products and services are not only the measurement scale to identify the Islamic stock but also it must cover the shariah requirements. More clearly, shariah based stock should be interest free and in accordance with shariah law and Islamic product and services should have shariah board and interest free in accordance with shariah law. Nevertheless, we are not free from interest perfectly, so these outcomes will not come naturally and without any cost. If government can establish money market without interest and with Islamic environment then we will get 
Islamic stock but Islamic stock market will be so far and depends on the investors' willingness and moral behaviour.

\section{CONCLUSION}

On the basis of investors' perception, they have no intention to transfer this market into Islamic stock market, but they want to enjoy all the opportunities of Islamic stock market i.e. they want to get benefit without any cost. The researchers want to make conclusion in a way of that for getting all Muslims final out comes, market should be transferred into Islamic stock Market. But this is not possible because of investors demand and our economic environment, capital \& money market, and rules \& regulations which are existing to use exchange or trade. However, most of the prerequisites for a natural birth of such a market do not exist at present. Therefore, endeavors should be made for their realization and revolution that will help for setting up such a secondary Islamic stock market. Customers are always right and priority should be given for them. So investors' expectation can change the present market or establish a separate Islamic stock market. If investors want to get Islamic environment; Islamic money and stock market; interest free transaction; gambling \& other illogical factors free market, they can get it because they are the driving factor to do this and government should honor to fulfill investors demand by the help of SEC \& DSE. In this situation, we need to win the confidence of people in the securities issued on an Islamic basis, and persist in infiltrating the present conventional stock markets with a view to Islamizing their activities. Even it will be caused of creating a better climate for Islamic stock and a gradual transformation into an Islamic stock market. But it can only be achieved when the shariah-based investment projects realize actual success by the help of Muslim investors. Recent and early stock market crash ask to search the way how to overcome these problems \& need to know the right path (as a Muslim) of trading shares. This study has revealed that owners of the outstanding share desire to get shariah rules \& regulations; separate Islamic stock market; shariah compliant products \& services and equity based securities priority basis. But they are not intended to transfer existing stock market. Reliability test of Cronbach Alpha coefficient claims that the test variable items are accepted. Therefore, respective authority \& government may go to start separate Islamic stock market with the help of 15 shariah based Islamic stock and 165 product \& service view Islamic stock. Here, researchers mention one thing that investors want to get separate Islamic stock market but they do not want to dump traditional stock market. It may be the indication of getting Islamic stock market test with having traditional market \& whenever they will prove the superiority of Islamic stock market over traditional with maximum profit from stable Islamic stock market, then they will accept it, unless they will continue traditional stock business.

The study believes that, if separate Islamic stock market is not established by the government, individual and other responsible authorities, as a Muslim we cannot solve the issues of halal and haram from the stock business. The study argues that Islamic stock market adopts a dynamic approach towards the development of just, sound, less risky and ethically balanced stock market. No doubt, this type of market can incorporate many products of the conventional stock market directly or with some modification of its features and functions and prohibits others. The Muslim government, companies, agencies and the intellectual Muslim investors should play its due role to establish Islamic stock market as to face the challenges of the conventional interest and gambling based security market. 


\section{RECOMMENDATION}

The international financial crisis has set the stage for Islamic finance to demonstrate a genuine alternative global financial system with halal and moral values. Study may conclude about the investors' perception that investors want to get separate Islamic stock market not to transfer existing stock market. Islamic securities can be the opportunities to issue, purchase and for trading benefit to the economy. In this regards, Dhaka stock exchange hopefully may make a list of shariah compliant stock that lead to start an Islamic stock market for local and foreign Muslim investors. Finally Islamic stock market is the consequence of some activities that must be act together. To make a complete Islamic stock market we need Islamic stock and that is the innovation of Islamic shariah based company. Islamic company depends upon the Islamic capital market which is the part of Islamic economy. However we cannot imagine Islamic economy if there is no shariah board, Islamically government and Islamic rules \& regulations. Moreover, investors are the driver of the economy and if, they have no Islamic concept in thinking and practice, all the attempts will be worthless. Needless to say that to improve the investors' perception to introduce Islamic stock market would require an academic effort and field work by a full research team for a considerable period of time. However as a Muslim government, they should train up the investors by providing Islamic concepts, rules and regulations under the control of shariah board. As participating organizations either full fledged or 'window' basis, brokerage house can play the vital role in accordance with shariah principles to carry out the Islamic stock broking business to the separate Islamic stock market. Last but not least government should take necessary actions to make separate Islamic market by which investors can make their investment to the Islamic stock market or to the conventional market according to their desire. Next study may be conducted on how government can establish separate Islamic stock market or how much superior Islamic stock market will have over traditional market.

\section{REFERENCES}

Ahmed, H (2009). Financial Crisis: Risks and Lessons for Islamic Finance ISRA International Journal of Islamic Finance 1(1).

Brooks, D (2009). An Economy of Faith and Trust. New York Times.

Chapra, U (2008). The Global Financial Crisis and the Islamic Financial System. Paper presented at the Forum On The Global Financial Crisis, Islamic Development Bank.

Coval, Joshua \& Stafford, Erik, 2007. "Asset fire sales (and purchases) in equity markets," Journal of Financial Economics, Elsevier, vol. 86(2): 479-512.

Fahd Bin Abdur Rahman Al-Yahya. 2007, At- Takyif Al-Fiqhi Li as-Saham fi Ash-Sharikat AlMusahamah Wa 'Asruhu, Daru Kunuji Isbilia, Riyadh

Gooden, S (2011). Islamic Finance and its application in Housing Projects. Housing Finance International PP 43-49.

Haque, M. S., (2012). Recent stock market crash in Bangladesh. [Internet], Available from:< http:/ / www.nub.ac.bd/recent-stock-market-crash-in-bangladesh-wrong-signals-from-

responsible-quarters-since-the-ctg-caused-the-asset-price-bubble/> [Accessed April 29 2012].

Helly E Robbins(2010). Soul searching and profit seeking. Texas Law Review Vol.88 1125-1150

Hossain M. K., 2011. Securities And Exchange Commission Annual Report 2010-11.

Ibn. Taymiyah, Ahmad Bin Abdul Halim. 1999, Al-Qawa'id An Nuraniyyah, Dar al- Ma'rifah, Beirut.

Islamic capital market fact finding report (2004), Report of the Islamic capital market task force of the international organization of securities commissions.

Khaled K. I., 2011. Investigation report of Probe Committee. 
Mohd. Yusof, R. and Abd. Majid, M.S. (2006). Policy and Persistence of Stock ReturnsVolatility: Conventional versus Islamic Stock Market. Journal of International Business and Entrepreneurship.Vol. 12(1): 49-68.

Mohd. Yusof, R. and Abd. Majid, M.S. (2007). Stock Market Volatility Transmission in Malaysia: Islamic versus Conventional Stock Market. Isalmic Economic Journal King Abdul Aziz University.Vol.20(2): 17-35

Muradoglu, G. Berumet, H. and Metin, K. (1999). Financial Crisis and Changes in Determinants of Risk and Return: An Empirical Investigation of an Emerging Market (ISE). Multinational Finance Journal. 3(4): 223-252.

Rahman, A and Ahmed, Y (1995). Islamic securities in Muslim countries' stock markets and an assessment of the need for an Islamic secondary market. Islamic Economics Studies, 3(1): 47.

Robert J Shiller (2003) From efficient markets theory to behavioral finance, Journal of economic perspectives 17 (1): 83-104

Samad, A and Hassan, M, K (1999). The performance of malaysian Islamic bank during 1984-1997: an exploratory study, International Journal of Islamic Financial Services 1(3):

Sangit Saha (2012) Stock market crash of Bangladesh in 2010-11: Reasons \& roles of regulators thesis paper page 50

Shahjahan H Bhuiyan (2011). Social Capital and Community Development: An Analysis of Two Cases from India and Bangladesh Journal of Asian and African Studies 46 (6): 533-545

Siddiqi, M. Nejatullah (2008). Current Financial Crisis and Islamic Economics. Mimeo, Oct 31.

Zaky,Nublan Zky Dato Yusoff Zaky(1992). An Islamic perspective of Stock Market-An Introduction, Dian Darulnaim Sdn. Bhd.Malaysia. page 71

\section{CALl for Paper}

American Journal of Trade and Policy

(AJTP) is an open-access, peer-reviewed interdisciplinary journal which seeks articles from any broad theme of international trade. AJTP features reports on current developments in international trade as well as on related policy issues. The digital online version is published by AJTP, and the hard copy (print) version is published by Asian Business Consortium

(ABC). Web: www.ajtp.us
Engineering International (EI) is a peerreviewed multi-disciplinary international journal devoted to academic advanced research from the engineering arena. It specializes in the publication of comparative thematic issues as well as individual research articles, review essays, and book reviews. Committed to disseminating rigorous scientific research to the widest possible audience, EI is fully and freely accessible on line. Web: www.j-ei.us 